\title{
IMPLEMENTASI QUALITY FUNCTION DEPLOYMENT UNTUK MENINGKATKAN KUALITAS JASA PENDIDIKAN DI UNIVERSITAS ISLAM RIAU
}

\section{IMPLEMENTATION OF QUALITY FUNCTION DEPLOYMENT TO IMPROVE THE QUALITY OF EDUCATION SERVICE IN UNIVERSITAS ISLAM RIAU}

\author{
Suyadi $^{1}$, Hafidzah Nurjannah ${ }^{2}$ \\ Univesitas Islam Riau ${ }^{1,2}$ \\ suyadi@eco.uir.ac.id ${ }^{1}$
}

\begin{abstract}
Competition in higher education institutions requires that these universities must be able to compete with other universities, especially in terms of education services. Where services should be maximized in satisfying students so that our tertiary institutions can be the first choice for students who will continue their studies. The purpose of this study is to find out what attributes are needs and expectations needed by students so that students feel satisfied with the services provided by the university. The population in this study were all active students of the Islamic University of Riau, while the sample selection was performed using Simple Random Sampling techniques of 398 students. The techniques in analyzing the data used are, Kano Model and QFD. The results showed there were 27 attributes, there were 2 answers contained in the canoe model category, including 25 attributes included in the one-dimensional category and 2 attributes included in the attractive category. The quality is still unsatisfactory seen from the calculation of the value of GAP which has 21 negative gap values. From 27 quality attributes, there are 7 priority attributes that need to be improved and there are 10 technical responses that must be improved to meet student satisfaction.
\end{abstract}

Keywords : Quality Function Deployment and Quality of Education Service

\begin{abstract}
ABSTRAK
Persaingan Perguruan Tinggi yang semakin pesat menuntut perguruan tinggi tersebut harus dapat bersaing dengan perguruan tinggi lainnya terutama dalam hal pelayanan jasa pendidikan. Dimana pelayanan harus lebih dimaksimalkan dalam memuaskan mahasiswa sehingga perguruan tinggi kita dapat menjadi pilihan pertama untuk mahasiswa yang akan melanjutkan belajarnya. Tujuan penelitian ini untuk mengetahui atribut apa yang menjadi kebutuhan dan harapan yang diperlukan mahasiswa sehingga mahasiswa merasa puas terhadap pelayanan yang diberikan oleh pihak universitas. Populasi dalam penelitian ini adalah seluruh mahasiswa aktif Universitas Islam Riau sedangkan pemilihan sampel dilakukan dengan menggunakan teknik Simple Random Sampling sebanyak 398 mahasiswa. Adapun teknik dalam menganalisa data yang digunakan yaitu, Model Kano dan QFD. Hasil penelitian menunjukan terdapat 27 atribut terdapat 2 jawaban yang terdapat pada kategori model kano antara lain 25 atribut termasuk kategori one dimensional dan 2 atribut yang termasuk kategori attractive.
\end{abstract}


Kualitas masih kurang memuaskan dilihat dari perhitungan nilai GAP yang terdapat 21 nilai gap negatif. Dari 27 atribut kualitas terdapat 7 atribut perioritas kebutuhan yang harus diperbaiki dan terdapat 10 respon teknis yang harus ditingkatkan untuk memenuhi kepuasan mahasiswa.

Kata Kunci: Quality Function Deployment dan Kualitas Jasa Pendidikan

\section{PENDAHULUAN}

Semakin pesatnya perkembangan ilmu dan teknologi di Indonesia, membuat kondisi persaingan pasar perguruan tinggi sebagai suatu institusi yang bergerak dibidang jasa harus memberikan pelayanan jasa yang berkualitas dan selalu memenuhi kebutuhan serta keingian para pengguna jasa (Suhendar 2014) . Kualitas yang dimaksud dalam perguruan tinggi berupa kemampuan lembaga pendidikan dalam mendayagunakan sumber-sumber pendidikan (Hutabri, 2017) untuk meningkatkan kemampuan belajar seoptimal mungkin.

Kualitas dan ilmu pengetahuan merupakan target yang sulit dipahami dalam banyak pelayanan (Nurjannah et al., 2020), terkadang merupakan pekerjaan yang bersifat intangible yang artinya tidak dapat dilihat, dicium dan didengar namun dapat dirasakan oleh pelanggan (Maulia et al., 2013). Selain itu, perguruan tinggi harus dapat memberikan atribut yang menjadi prioritas kebutuhan mahasiswa sehingga perguruan tinggi tersebut mampu bersaing dengan perguruan tinggi lainnya (Nurjannah et al., 2019).

Dalam upaya peningkatan kualitas jasa ada beberapa alat analisis pengukuran antara lain Quality function Deployment (QFD). Quality Function Deployment $(Q F D)$ adalah metode yang digunakan untuk membuat perencanaan produk atau jasa yang dilakukan oleh tim pengembangan dengan mencari keinginan dan kebutuhan pelanggan kemudian mengevaluasi usaha-usaha untuk mencapai tujuan tersebut.
Penelitian terhadap kualitas perlu dilakukan oleh Khamseh (2011). dalam upaya meningkatkan kualitas jasa dengan tujuan peningkatan mutu pelayanan jangka panjang dan untuk mempertahankan kepuasan mahasiswa yang ada di Riau khususnnya pada Universitas Islam Riau. Perguruan tinggi swasta yang ada di kota pekanbaru, yang beralamat di $\mathrm{Jl}$ Kaharuddin Nasution No 133 pekanbaru, Riau, yang didirikan oleh Yayasan Lembaga Pendidikan Islam (YLPI).

Sehingga masalah yang dihadapi Universitas Islam Riau adalah terdapat sarana dan prasarana yang kurang memadai, Terdapat layanan yang kurang memuaskan oleh sebagian mahasiswa seperti lamanya pengurusan surat menyurat. Pelayanan yang kurang memuaskan dibeberapa departemen seperti pelayanan perpustakaan yang sering terjadinya sistem error saat peminjaman buku, serta terdapat beberapa lahan parkir yang tidak memadai di beberapa fakultas. Kerusakan pada Electronik Gate (EGate) yang mengakibatkan petugas melakukan pemeriksaan manual yang menjadikan antrian keluar pada Universitas Islam Riau. Sehingga penelitian ini mengangkat topik Quality Function Deployment (QFD) untuk meningkatkan kualitas jasa pendidikan pada Universitas Islam Riau.

\section{METODE PENELITIAN}

Penelitian ini dilakukan di Universitas Islam Riau dengan mahasiswa aktif sebagai sampel sebesar 
394 orang yang penentuan jumlah sampelnya dihitung menggunakan formulasi slovin. Sedangkan pemilihan sampel dilakukan dengan menggunakan purpossive sampling. Penelitian ini dianalisis dengan menggunakan model Quality Function Deployment (QFD) dan matrik House of Quality (HoQ). Teknik pengumpulan data yang diperoleh dari penelitian ini menggunakan interview kepada pihak Lembaga Penjamin Mutu (LPM) dan mahasiswa untuk mendapatkan atribut yang diperlukan dalam membuat angket yang nantinya akan diuji validitas dan reliabilitas kemudian disebarkan kembali kepada mahasiswa selaku pengguna jasa pendidikan.

\section{HASIL DAN PEMBAHASAN \\ Pengolahan Data Quality Function Deployment (QFD)}

Untuk menggunakan model QFD, penelitian ini menggunaka analisis matrik House of Quality (HoQ). HoQ digunakan untuk mengetahui atribut yang menjadi keinginan mahasiswa yang akan dihubungkan dengan karakteristik kualitas laanan akademik kampus sehingga menghasilkan hubungan antara keinginan mahasiswa dan dengan karakteristik universitas dalam matrik hubungan. Selain itu, dari matrik HoQ dapat menunjukkan antar hubungan yang kuat, sedang, lemah, dan tidak memiliki hubungan sehingga korelasi tersebut akan diperoleh target nilai yang akan digunakan sebagai tingkatan prioritas dalam pengembangan, peningkatan, dan pengendalian setiap karakreristik kualitas pelayanan terhadap mahasiswa (Suhendar 2014).

\section{Matrik House of Quality (HoQ) \\ Kebutuhan dan Harapan Pelangan (Customer Needs and Benefits)}

Pada tahap ini, peneliti melakukan observasi, interview, dan penyebaran angket/kuesioer kepada mahasiswa guna mendapatkan informasi terkait apa yang menjadi kebutuhan dan keingin mahasiswa terhadap pelayanan jasa pendidikan yang harus diberikan oleh pihak kampus yaitu Universitas Islam Riau. Tabel 1 berikut merupakan atribut yang menjadi kebutuhan dan keinginan mahasiswa yang terdiri dari 100 responden.

Tabel 1. Atribut Keinginan Mahasiswa terhadap Pelayanan Jasa Pendidikan

\begin{tabular}{|c|c|}
\hline No & Atribut \\
\hline 1 & $\begin{array}{l}\text { Seleksi calon mahasiswa baru } \\
\text { dilaksanakan secara selektif dan cepat }\end{array}$ \\
\hline 2 & $\begin{array}{l}\text { Pelayanan akademik secara online dan } \\
\text { manual efektif dan cepat }\end{array}$ \\
\hline 3 & $\begin{array}{l}\text { Staff akademik melayani dengan tulus } \\
\text { hati, ramah dan sabar }\end{array}$ \\
\hline 4 & $\begin{array}{l}\text { Staff administrasi akademik tanggap } \\
\text { menangani keluhan dan permintaan } \\
\text { mahasiswa terkait pelayanan } \\
\text { administrasi }\end{array}$ \\
\hline 5 & $\begin{array}{l}\text { Informasi akademik mudah diperoleh, } \\
\text { cepat dan akurat }\end{array}$ \\
\hline 6 & $\begin{array}{l}\text { Proses pengisian KRS online yang } \\
\text { sangat mudah bagi mahasiswa. }\end{array}$ \\
\hline 7 & $\begin{array}{l}\text { Prosedur pendaftaran dan pembayaran } \\
\text { uang perkuliahan jelas }\end{array}$ \\
\hline 8 & $\begin{array}{l}\text { Fasilitas kelas (meja, kursi, papan tulis, } \\
\text { pendingin ruangan, infocus) memadai }\end{array}$ \\
\hline 9 & Fasilitas kesehatan memadai \\
\hline 10 & Fasilitas kegiatan olahraga memadai \\
\hline 11 & $\begin{array}{l}\text { Fasilitas perpustakaan yang memadai } \\
\text { (buku, jurnal proceeding, dan artikel) }\end{array}$ \\
\hline 12 & Tersedianya akses e-library \\
\hline 13 & $\begin{array}{l}\text { Lingkungan kampus bersih aman (ada } \\
\text { security dan cctv) }\end{array}$ \\
\hline 14 & Kemudahan akses internet \\
\hline 15 & $\begin{array}{l}\text { Tersedianya labor komputer yang } \\
\text { memadai }\end{array}$ \\
\hline 16 & Ketersediaan sarana parkir \\
\hline 17 & $\begin{array}{l}\text { Tersedianya sarana mushala/mesjid dan } \\
\text { toilet yang bersih }\end{array}$ \\
\hline 18 & $\begin{array}{l}\text { Pengajaran sesuai dengan Renacana } \\
\text { Pembelajaran Semester (RPS) }\end{array}$ \\
\hline 19 & $\begin{array}{l}\text { Dosen mematuhi jadwal perkuliahan } \\
\text { yang ditetapkan }\end{array}$ \\
\hline
\end{tabular}




\begin{tabular}{cl}
\hline 20 & $\begin{array}{l}\text { Metode penilaian dan prosedur penilaian } \\
\text { dilakukan secara transparan dan } \\
\text { subyektif }\end{array}$ \\
\hline 21 & $\begin{array}{l}\text { Ujian dilaksanakan sesuai jadwal yang } \\
\text { tersaji dalam Kalender Akademik }\end{array}$ \\
\hline 22 & $\begin{array}{l}\text { Nilai Ujian dapat keluar tepat waktu } \\
\text { tidak lebih dari 2 minggu setelah ujian }\end{array}$ \\
\hline 23 & $\begin{array}{l}\text { Sebagai pembimbing akademis, dosen } \\
\text { dapat membantu mahasiswa dalam } \\
\text { menyelesaikan masalah perkuliahan }\end{array}$ \\
\hline 24 & Kemampuan berorganisasi \\
\hline 25 & $\begin{array}{l}\text { Kemampuan penggunaan informasi } \\
\text { akademik (sikad) }\end{array}$ \\
\hline 26 & Kemampuan berbahasa internasional \\
\hline 27 & Kemampuan membaca Al-qur'an
\end{tabular}

Sumber : Data Olahan (2019)

\section{Penentuan Prioritas Kebutuhan}

Analisis prioritas kebutuhan dibutuhkan untuk memproleh nilai adjusted importance yang dapat digunakan untuk memperoleh nilai prioritas respon teknis yang diperlukan

\section{Technical Response (Parameter Teknik, Pengembangan Bahasa Pelanggan)}

1. Meningkatkan pengembangan kurikulum berdasarkan KKNI

2. Meningkatkan pengembangan dosen melalui pendidikan dan pelatihan

3. Melakukan audit mutu

4. Meningkatkan sistem pelayanan akademik

5. Meningkatkan sistem pelayanan administrasi

6. Meningkatkan penggunakaan laboratorium

7. Meningkatkan fasilitas internet

8. Meningkatkan e-library

9. Meningkatkan sarana dan prasarana oleh pihak manajemen perguruan tinggi dalam memperbaiki dan meningkatkan kualitas. Dibawah ini merupakan hasil dari perioritas kebutuhan sebagai berikut:

Tabel 2. Hasil Analisis Prioritas Kebutuhan

\begin{tabular}{|c|c|c|c|c|c|c|}
\hline No & Atribut & Kepentingan & GAP & $\begin{array}{c}\text { Adjusted } \\
\text { Importance }\end{array}$ & $\%$ & Rank \\
\hline 1 & $\begin{array}{l}\text { Seleksi calon mahasiswa baru } \\
\text { dilaksanakan secara selektif dan cepat }\end{array}$ & 4,55 & $-1,51$ & 13,74 & 7,09 & \\
\hline 2 & $\begin{array}{l}\text { Staff akademik melayani dengan tulus } \\
\text { hati, ramah dan sabar }\end{array}$ & 4,55 & $-1,51$ & 13,74 & 5,03 & 7 \\
\hline 3 & $\begin{array}{l}\text { Staff administrasi akademik tanggap } \\
\text { menangani keluhan dan permintaan } \\
\text { mahasiswa terkait pelayanan } \\
\text { administrasi. }\end{array}$ & 4,47 & $-1,09$ & 9,74 & 6,32 & 5 \\
\hline 4 & $\begin{array}{l}\text { Informasi akademik mudah diperoleh, } \\
\text { cepat dan akurat }\end{array}$ & 4,47 & $-1,37$ & 12,25 & 4,77 & \\
\hline 5 & $\begin{array}{l}\text { Proses pengisian KRS online yang } \\
\text { sangat mudah bagi mahasiswa. }\end{array}$ & 4,49 & $-1,03$ & 9,25 & 7,09 & 4 \\
\hline 6 & $\begin{array}{l}\text { Prosedur pendaftaran dan pembayaran } \\
\text { uang perkuliahan jelas. }\end{array}$ & 4,55 & $-1,51$ & 13,74 & 2,53 & \\
\hline 7 & $\begin{array}{l}\text { Fasilitas kelas (meja, kursi, papan } \\
\text { tulis, pendingin ruangan, infocus) } \\
\text { memadai. }\end{array}$ & 4,46 & $-0,55$ & 4,91 & 5,77 & \\
\hline
\end{tabular}




\begin{tabular}{|c|c|c|c|c|c|c|}
\hline No & Atribut & Kepentingan & GAP & $\begin{array}{c}\text { Adjusted } \\
\text { Importance }\end{array}$ & $\%$ & Rank \\
\hline 8 & Fasilitas kesehatan memadai. & 4,58 & $-1,22$ & 11,18 & 5,67 & \\
\hline 9 & Fasilitas kegiatan olahraga memadai. & 4,36 & $-1,26$ & 10,99 & 7,52 & \\
\hline 10 & $\begin{array}{l}\text { Fasilitas perpustakaan yang memadai } \\
\text { (buku, jurnal proceeding, dan artikel). }\end{array}$ & 3,92 & $-0,93$ & 14,58 & 4,79 & 1 \\
\hline 11 & Tersedianya akses e-library. & 4,6 & $-1,01$ & 9,29 & 5,41 & \\
\hline 12 & $\begin{array}{l}\text { Lingkungan kampus bersih aman (ada } \\
\text { security dan cctv) }\end{array}$ & 4,23 & $-1,24$ & 10,49 & 4,32 & \\
\hline 13 & Kemudahan akses internet. & 4,55 & $-0,92$ & 8,37 & 6,80 & \\
\hline 14 & $\begin{array}{l}\text { Tersedianya labor komputer yang } \\
\text { memadai. }\end{array}$ & 4,61 & $-1,43$ & 13,18 & 4,88 & \\
\hline 15 & Ketersediaan sarana parkir. & 4,46 & $-1,06$ & 9,46 & 4,22 & 6 \\
\hline 16 & $\begin{array}{l}\text { Tersedianya sarana mushala/mesjid } \\
\text { dan toilet yang bersih. }\end{array}$ & 4,49 & $-0,91$ & 8,17 & 4,66 & \\
\hline 17 & $\begin{array}{l}\text { Pengajaran sesuai dengan Rencana } \\
\text { Pembelajaran Semester (RPS). }\end{array}$ & 4,61 & $-0,98$ & 9,04 & 2,88 & 2 \\
\hline 18 & $\begin{array}{l}\text { Dosen mematuhi jadwal perkuliahan } \\
\text { yang ditetapkan }\end{array}$ & 4,43 & $-0,63$ & 5,58 & 4,04 & 3 \\
\hline 19 & $\begin{array}{l}\text { Metode penilaian dan prosedur } \\
\text { penilaian dilakukan secara transparan } \\
\text { dan subyektif }\end{array}$ & 4,45 & $-0,88$ & 7,83 & 2,85 & \\
\hline 20 & $\begin{array}{l}\text { Staff administrasi akademik tanggap } \\
\text { menangani keluhan dan permintaan } \\
\text { mahasiswa terkait pelayanan } \\
\text { administrasi. }\end{array}$ & 4,38 & $-0,63$ & 5,52 & 3,28 & \\
\hline 21 & $\begin{array}{l}\text { Sebagai pembimbing akademis, dosen } \\
\text { dapat membantu mahasiswa dalam } \\
\text { menyelesaikan masalah perkuliahan. }\end{array}$ & 4,35 & $-0,73$ & 6,35 & 0,10 & \\
\hline 22 & Kemampuan berorganisasi & 3,07 & $-0,03$ & 0,18 & 7,09 & \\
\hline
\end{tabular}

Sumber : Data Olahan (2019) 


\section{Penentuan Response Teknis}

Prioritas respon teknis didapatkan dengan cara mengalikan adjusted importance dengan nilai pada matriks hubungan antara kebutuhan konsumen dan respon teknis. Pada matriks hubungan, hubungan sangat kuat bernilai sembilan, hubungan kuat bernilai tiga dan hubungan lemah bernilai satu. Hasil analisis prioritas teknis yang diperoleh dapat dilihat pada tabel di bawah ini:

Tabel 3. Analisis Prioritas Respon Teknis

\begin{tabular}{|c|c|c|c|}
\hline No & Respon Teknis & Prioritas & $\%$ \\
\hline 1 & $\begin{array}{l}\text { Meningkatkan } \\
\text { pengembangan } \\
\text { kurikulum } \\
\text { berdasarkan } \\
\text { KKNI }\end{array}$ & 78.11 & 5.90 \\
\hline 2 & $\begin{array}{l}\text { Meningkatkan } \\
\text { pengembangan } \\
\text { dosen melalui } \\
\text { pendidikan dan } \\
\text { pelatihan }\end{array}$ & 50.24 & 3.79 \\
\hline 3 & $\begin{array}{l}\text { Melakukan audit } \\
\text { mutu }\end{array}$ & 494.72 & 37.36 \\
\hline 4 & $\begin{array}{l}\text { Meningkatkan } \\
\text { sistem pelayanan } \\
\text { akademik }\end{array}$ & 286.63 & 21.65 \\
\hline 5 & $\begin{array}{l}\text { Meningkatkan } \\
\text { sistem pelayanan } \\
\text { administrasi }\end{array}$ & 87.70 & 6.62 \\
\hline 6 & $\begin{array}{l}\text { Meningkatkan } \\
\text { penggunaan } \\
\text { laboratorium }\end{array}$ & 5.58 & 0.42 \\
\hline 7 & $\begin{array}{l}\text { Meningkatkan } \\
\text { fasilitas internet }\end{array}$ & 158.48 & 11.97 \\
\hline 8 & $\begin{array}{l}\text { Meningkatkan e- } \\
\text { library }\end{array}$ & 5.58 & 0.42 \\
\hline 9 & $\begin{array}{l}\text { Meningkatkan } \\
\text { sarana dan } \\
\text { prasarana }\end{array}$ & 157.17 & 11.87 \\
\hline
\end{tabular}

Pada tabel 3 terdapat empat perioritas respon teknis yang harus dilakukan lembaga perguruan tinggi swasta pada Universitas Islam Riau untuk memenuhi kebutuhan mahasiswa yakni dengan melakukan audit mutu, meningkatkan sistem pelayanan akademik, meningkatkan fasilitas internet, serta meningkatkan sarana dan prasarana. Hamengkubuwono (2017) dalam penelitiannya juga menemukan pentingnya peran audit mutu internal pada perguruan tinggi dalam membantu meningkatkan kualitas dari perguruan tinggi.

\section{Matriks House of Quality (HoQ)}

Matriks ini menjelaskan atribut yang dapat dijadikan sebagai parameter oleh Universitas Islam Riau dalam memenuhi apa yang dibutuhkan dan diinginkan oleh mahasiswa terkait pelayanan jasa pendidikan yang diberikan oleh lembaga tersebut. Gambar tersebut dapat dilihat pada Gambar 1. House of Quality

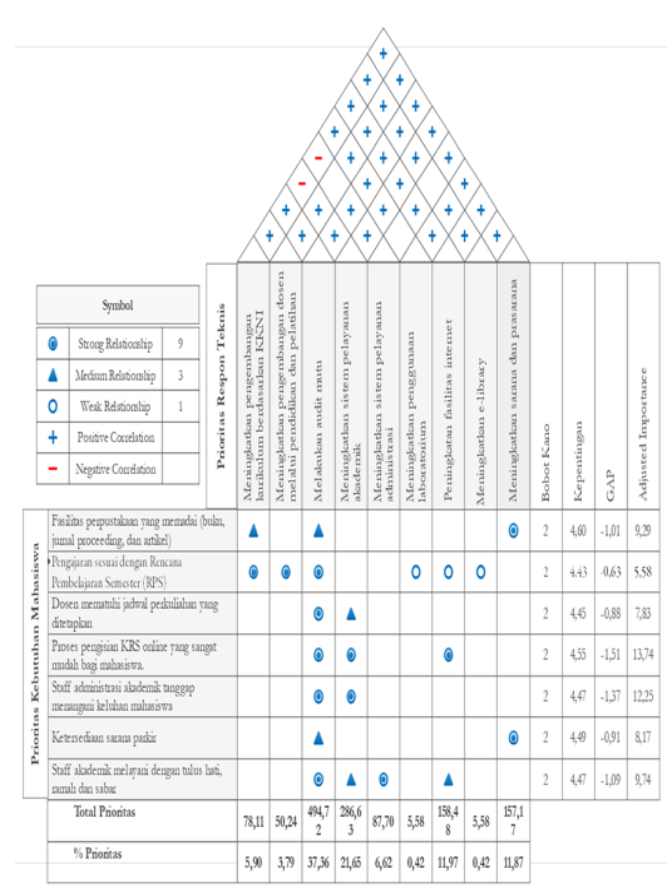

Gambar 1. House of Quality

\section{PENUTUP \\ Kesimpulan}

Dari hasil penelitian dan pembahasan yang telah dilakukan, dapat ditarik kesimpulan yakni: 
1. Ada tujuh atribut yang menjadi prioritas kebutuhan mahasiswa yang harus dipenuhi oleh pihak kampus yaitu Fasilitas perpustakaan yang memadai (buku, jurnal proceeding, dan artikel), Pengajaran sesuai dengan Rencana Pembelajaran Semester (RPS), dosen mematuhi jadwal kuliah yang telah ditetapkan, proses pengisian KRS online yang mudah bagi mahasiswa, Staff administrasi akademik tanggap menangani keluhan dan permintaan mahasiswa terkait pelayanan administrasi, Ketersediaan sarana parkir, Staff akademik melayani dengan tulus hati, dan ramah dan sabar.

2. Berdasarkan pada analisis pioritas respon teknis, terdapat empat yang harus dilakukan lembaga perguruan tinggi swasta pada Universitas Islam Riau untuk memenuhi kebutuhan mahasiswa yakni dengan melakukan audit mutu, meningkatkan sistem pelayanan akademik, meningkatkan fasilitas internet, serta meningkatkan sarana dan prasarana.

\section{Saran}

yang Pada nilai adjusted importance memperoleh nilai prioritas respon teknis yang terdiri antara lain: Fasilitas perpustakaan yang lengkap (buku, ruang baca, kamar mandi, komputer), Dosen menyediakan rencana pelaksanaan pembelajaran/ RPP, Pengisian KRS online yang sangat mudah bagi mahasiswa, Staff administrasi akademik tanggap menangani keluhan dan permintaan mahasiswa, Ketersediaan sarana parkir, Staff akademik (TU) melayani mahasiswa dengan ramah. Dari prioritas respon teknis diatas pihak manajemen perguruan tinggi Universitas Islam Riau sebaikmya memperbaiki dan meningkatkan kualitas untuk memenuhi kepuasan mahasiswa, mencapai visi missi organisasi.

\section{DAFTAR PUSTAKA}

Hamengkubuwono, H. (2017). Implementasi Audit Mutu Internal Pada Perguruan Tinggi Agama. BELAJEA: Jurnal Pendidikan Islam, 2(1), 55.

Hutabri, E. (2017). Penerapan Metode Kano dalam Analisis Tingkat Kepuasan Mahasiswa Terhadap Penerapan Sistem Informasi Akademik Berbasis Web. Sumatra Barat: Jurnal Edik Informatika.

Khamseh, A. (2011). Integrating Kano's Model into Quality Function Deployment (QFD) to Optimally Identify and Prioritize the Needs of Higher Education (case study: Engineering Faculty of Tarbiat Moallem University). Institute of Interdisciplinary Business Research.

Maulia, E., Matondang A. R. \& Ginting R. (2013). Analisis Kepuasan Pelanggan Dengan Pendekatan Model Kano Serta Aplikasi Quality Function Deployment (QFD) Untuk Meningkatkan Mutu Pelayanan Jasa Perbankan. Jurnal Teknik Industri USU. 2(1): 1-7.

Nurjannah, H., Mardianty, Desy, H, Restu, S., Efi (2020). The Implementation of Kano Model and Quality Function Deployment (QFD) to Optimize the Quality of Higher Education in Indonesia. Espacios 41(6): 26. 
Nurjannah, H., Mardianty, D. (2019). Integrasi Model Kano Ke Dalam QFD Untuk Mengoptimalkan Kualitas Perguruan Tinggi Di Provinsi Riau. COSTING: Journal of Economic, Business and Accounting 3(1): 136-44.

Suhendar, E. (2014). Penerapan Metode Quality Function Deployment (QFD) Dalam Upaya Peningkatan Kualitas Pelayanan. Faktor Exacta 7(4): 372-86. 